\title{
Telemedicine for Patients with Schizophrenia: A Systematic Literature Review on Applications and Outcomes
}

\author{
Sareh Keshvardoost ${ }^{1}$, Elaheh Shafiei ${ }^{1}$, Sadrieh Hajesmaeel-Gohari ${ }^{1,{ }^{*},}$, Mostafa Hosseini Golkar ${ }^{2}$ and \\ Kambiz Bahaadinbeigy ${ }^{1}$ \\ ${ }^{1}$ Medical Informatics Research Center, Institute for Futures Studies in Health, Kerman University of Medical Sciences, Kerman, Iran \\ ${ }^{2}$ Health Foresight and Innovation Research Center, Institute for Futures Studies in Health, Kerman University of Medical Sciences, Kerman, Iran \\ "Corresponding author: Medical Informatics Research Center, Institute for Futures Studies in Health, Kerman University of Medical Sciences, Kerman, Iran. Email: \\ s.hajesmaeel@kmu.ac.ir \\ Received 2021 June 17; Revised 2021 December 19; Accepted 2021 December 19
}

\begin{abstract}
Context: Schizophrenia is one of the most severe mental disorders that affect all aspects of a patient's lives. Telemedicine can be helpful for this population.

Objectives: This study aimed to review the studies for investigating the applications and outcomes of telemedicine in providing healthcare services for patients with schizophrenia.

Evidence Acquisition: We searched PubMed and Scopus databases to find relevant studies in July 2020. The combination of two "Schizophrenia" AND "Telemedicine" keywords were used to search databases. Original observational and interventional studies, which have used a telemedicine service in schizophrenia disease, were included in this review.

Results: Of 309 gathered studies, 26 studies were entered into this research. The synchronous modality (58\%) and videoconference communication (38.5\%) were used in most studies. Most studies (84.5\%) have shown that telemedicine was a beneficial method. More than half of the studies (58\%) had therapeutic goals. The rest of the studies were for diagnostic (19\%), educational (11.5\%), and both therapeutic and educational (11.5\%) purposes. Only one study (4\%) showed that telemedicine was not cost-effective. In nine studies (34.5\%), users were satisfied with the use of telemedicine services.

Conclusions: Telemedicine is a useful method for the management of patients with schizophrenia, especially to improve treatment adherence and prevent relapse. It would be better to pay more attention to the educational issues because of the positive impact on adherence to treatment and prevent relapse.
\end{abstract}

Keywords: Review, Schizophrenia, Telemedicine, Telepsychiatry

\section{Context}

Schizophrenia is a chronic mental disease that affects over 20 million people worldwide (1). It is usually diagnosed at young age, between the second or third decade of a patient's life, and occurs more rapidly in men than in women (2). Schizophrenia is recognized as one of the 15 leading causes of disability at an early age (2). This disease imposes huge indirect costs on the patient, family, and society by disrupting the individual's social functioning and reducing productivity, which is far more than its direct costs (3). Given that schizophrenia has a chronic and progressive course, treatment should be started as soon as possible. Late treatment can lead to many complications such as acute illness, isolation, aggression, suicidal ideation, attempt to harm others, alcohol and drug abuse, social dysfunction as employment and education, and ultimately in- creased direct and indirect treatment costs (4). However, some problems, such as limited access to psychiatric services and fear of the stigma of the disease, are factors that delay treatment (5).

In the new era, with telecommunication technology, receiving psychiatric services is no longer limited to faceto-face visits with specialists. In this regard, some studies have shown that telepsychiatry, as a subspecialty of telemedicine, increases the feeling of comfort and has improved the patient's clinical condition (6). In a Spaniel study, telepsychiatry was able to control the number of relapses and reduce hospitalization rates and visits (7). Modai et al., showed that the use of telepsychiatry increased treatment adherence in patients. Moreover, the satisfaction of both patients and therapists was at a high level (8). Also, during COVID pandemic, due to the restrictions on access to specialized medical services as well as the 
psychological burden of the disease, the need for telepsychiatry increased more than ever (9). Although such studies demonstrate the value of telemedicine in the management of patients with schizophrenia, it is necessary to conduct comprehensive research that considers the results of various studies to be able to judge based on more evidence.

In this regard, a study reviewed the types of telepsychiatric interventions for patients with schizophrenia in 2010. In this study, the interventions were classified into three groups based on communication methods: telephonebased, internet-based, and video-based. The results of this study showed the effectiveness of telepsychiatry in all three methods (10). Despite this study, considering the advancement of telemedicine science since that time to date, there is a need to conduct a new review study.

\section{Objectives}

In this study, we aimed to have a comprehensive review of the studies to find out in which areas telepsychiatry has been used more or less for schizophrenic patients, and in which areas it has been able to succeed so that investors and health policymakers can focus on it. In fact, we aimed to answer the following questions:

In which countries the telemedicine projects were done?

What telemedicine modalities were used in the studies?

What telecommunication methods were used in the studies?

What were the objectives of implementing telemedicine-schizophrenia in the studies?

Who were participated in the use of telemedicine?

What were the outcomes of telemedicine services (clinical, cost-effectiveness, and satisfaction)?

The results of this systematic review will provide a comprehensive view for health services and decision-makers to know about telemedicine capabilities to support patients with schizophrenia, and also helpful to the better move toward establishing a telemedicine system for the management of schizophrenia disease.

\section{Evidence Acquisition}

\subsection{Search Strategy}

We searched PubMed and Scopus databases in July 2020 to access the literature without time limitations. The combination of two "Schizophrenia" AND "Telemedicine" keywords were used to search all fields of the PubMed and the "title and abstract" field of the Scopus.

\subsection{Inclusion Criteria}

Studies were included in the review if they had the following criteria: studies which have been written in English language; original (observational and interventional) studies, which have reported a telemedicine interventional study focused on schizophrenia disease; studies in which there was an interactive communication between two participants.

\subsection{Exclusion Criteria}

Studies with the following criteria were excluded from this review: without abstract, letter, commentary, editorial, review studies, book chapters, conference papers, studies without full-text, not compliance with goals (studies that did not focus only on patients with schizophrenia and the results were not reported in schizophrenia, descriptive studies that did not report implementation results, and studies without two-way communication such as self-report and self-management)

\subsection{Selection Strategy}

One of the authors (S.H) performed the literature search and entered the retrieved studies into EndNote X8 bibliographic software, and removed duplicate studies. Two other authors (S.K and E.SH) reviewed the title and abstract of the studies independently. Eventually, after reading full-text, final papers were re-checked precisely according to the study inclusion and exclusion criteria. Disagreements at any stage of study were solved by the telemedicine expert's opinion (K.B).

\subsection{Data Extraction}

Data were extracted from final studies by two evaluators independently and entered into a checklist containing author, country, telemedicine modality, telecommunication method, objective of the study, participants, clinical outcome, cost-effectiveness, and satisfaction criteria.

\section{Results}

PubMed and Scopus database search was resulted in retrieving 309 studies. After removing 107 duplicate studies, 202 studies screened using titles and abstracts. In the next step, 67 studies were selected for further review based on full-text (Figure 1).

Finally, 26 studies were included in this review study and data were extracted from them (Table 1). 


\begin{tabular}{|c|c|c|c|c|c|c|c|c|}
\hline \multirow{2}{*}{ Author } & \multirow{2}{*}{ Country } & \multirow{2}{*}{$\begin{array}{l}\text { Telemedicine } \\
\text { Modality }\end{array}$} & \multirow{2}{*}{$\begin{array}{l}\text { Telecommunication } \\
\text { Method }\end{array}$} & \multirow{2}{*}{ Objective and Category } & \multirow{2}{*}{ Participants } & \multicolumn{3}{|l|}{ Outcome } \\
\hline & & & & & & Clinical & $\begin{array}{l}\text { Cost Effec- } \\
\text { tiveness }\end{array}$ & Satisfaction \\
\hline $\begin{array}{l}\text { Chae et al. } \\
\text { (11) }\end{array}$ & Korea & Synchronous & $\begin{array}{l}\text { Video } \\
\text { conference }\end{array}$ & $\begin{array}{l}\text { To investigate reliability and acceptability of } \\
\text { low bandwidth (D) }\end{array}$ & $\begin{array}{l}\text { Physician, nurse, } \\
\text { patient }\end{array}$ & Reliability of services delivery were high & $\sqrt{ }$ & $\sqrt{ }$ \\
\hline $\begin{array}{l}\text { Yoshino et } \\
\text { al. (12) }\end{array}$ & Japan & Synchronous & $\begin{array}{l}\text { Video } \\
\text { conference }\end{array}$ & $\begin{array}{l}\text { To investigate reliability using the narrow and } \\
\text { broad bandwidth (D) }\end{array}$ & Patients, psychiatrists & $\begin{array}{l}\text { Reliability of psychiatric interview is } \\
\text { insufficient using narrow bandwidth but } \\
\text { broad bandwidth may permit reliable } \\
\text { diagnostic }\end{array}$ & - & . \\
\hline $\begin{array}{l}\text { Modai et } \\
\text { al. }(8)\end{array}$ & Israel & Synchronous & $\begin{array}{c}\text { Video } \\
\text { conference }\end{array}$ & $\begin{array}{l}\text { To compare hospitalization costs, treatment } \\
\text { adherence, patient and physician satisfaction, } \\
\text { and treatment safety }(\mathrm{T})\end{array}$ & Patients, physician & $\begin{array}{l}\text { Treatment was safe and effective; Adherence } \\
\text { was high }\end{array}$ & $\sqrt{ }$ & $\sqrt{ }$ \\
\hline $\begin{array}{l}\text { Shen et al. } \\
\text { (13) }\end{array}$ & USA & Synchronous & $\begin{array}{l}\text { Video } \\
\text { conference }\end{array}$ & $\begin{array}{l}\text { To Improve efficiency and evaluating a new } \\
\text { antipsychotic medication (T) }\end{array}$ & $\begin{array}{l}\text { Patient, remote } \\
\text { centralized raters }\end{array}$ & Efficiency of treatment was high & - & - \\
\hline $\begin{array}{l}\text { Spaniel et } \\
\text { al. (7) }\end{array}$ & $\begin{array}{c}\text { Czech } \\
\text { Republic }\end{array}$ & Asynchronous & SMS, E-mail & To prevention of relapse and readmission $(\mathrm{T})$ & $\begin{array}{l}\text { Professional, patient, } \\
\text { family members }\end{array}$ & $\begin{array}{l}\text { Significantly fewer hospitalizations; Control } \\
\text { the number of relapses }\end{array}$ & - & $\cdot$ \\
\hline $\begin{array}{l}\text { Rotondi et } \\
\text { al. }(14)\end{array}$ & USA & Synchronous & $\begin{array}{l}\text { Website } \\
\text { forum (dis- } \\
\text { cussions) }\end{array}$ & $\begin{array}{l}\text { To evaluation of patient knowledge and } \\
\text { symptoms (E\& } \mathrm{T} \text { ) }\end{array}$ & $\begin{array}{l}\text { Therapist, patient, } \\
\text { their support persons }\end{array}$ & $\begin{array}{l}\text { Significant improvement in knowledge and } \\
\text { positive symptoms }\end{array}$ & - & $\sqrt{ }$ \\
\hline $\begin{array}{l}\text { Haley et } \\
\text { al. (15) }\end{array}$ & Ireland & Synchronous & $\begin{array}{l}\text { Video } \\
\text { conference }\end{array}$ & $\begin{array}{l}\text { Efficacy of telepsychiatry in delivering a career } \\
\text { education program }(\mathrm{E})\end{array}$ & $\begin{array}{l}\text { Family members, } \\
\text { therapists }\end{array}$ & $\begin{array}{l}\text { Significantly improved knowledge and as } \\
\text { effective as education course delivered in } \mathrm{F} 2 \mathrm{~F}\end{array}$ & - & $\cdot$ \\
\hline $\begin{array}{l}\text { Franco- } \\
\text { Martin } \\
(16)\end{array}$ & Spain & Synchronous & $\begin{array}{l}\text { Video } \\
\text { conference }\end{array}$ & To evaluate the reliability (D) & Patients, evaluator & $\begin{array}{l}\text { Internet neuropsychological evaluation is } \\
\text { possible and reliable }\end{array}$ & - & $\cdot$ \\
\hline $\begin{array}{l}\text { Godleski } \\
\text { et al. }(17)\end{array}$ & USA & Hybrid & $\begin{array}{l}\text { Message } \\
\text { and call }\end{array}$ & $\begin{array}{l}\text { To assess the feasibility and hospital } \\
\text { utilization and ER visits (T) }\end{array}$ & $\begin{array}{l}\text { Veterans, nurse } \\
\text { practitioner }\end{array}$ & $\begin{array}{l}\text { Substantial reductions in hospitalization rates } \\
\text { and ER visit rates }\end{array}$ & - & $\sqrt{ }$ \\
\hline $\begin{array}{l}\text { Spaniel et } \\
\text { al. (18) }\end{array}$ & $\begin{array}{l}\text { Czech } \\
\text { Republic }\end{array}$ & Asynchronous & $\begin{array}{c}\text { SMS and } \\
\text { E-mail }\end{array}$ & Prevention of relapse and hospitalization $(\mathrm{T})$ & $\begin{array}{c}\text { Patients, family } \\
\text { members, psychiatrist }\end{array}$ & $\begin{array}{l}\text { Significantly reduced the risk of } \\
\text { hospitalization due to relapse, and decreased } \\
\text { the number of inpatient days }\end{array}$ & $\sqrt{ }$ & $\cdot$ \\
\hline $\begin{array}{l}\text { Ozkan et } \\
\text { al. }(19)\end{array}$ & Turkey & Synchronous & Call & $\begin{array}{l}\text { Effect of psychoeducation and telepychiatriy } \\
\text { follow-up (E) }\end{array}$ & Caregivers, researcher & $\begin{array}{l}\text { Decreased in family burden and depressive } \\
\text { symptoms }\end{array}$ & - & - \\
\hline $\begin{array}{l}\text { Temmingh } \\
\text { et al. (20) }\end{array}$ & $\begin{array}{l}\text { South } \\
\text { Africa }\end{array}$ & Synchronous & Call & $\begin{array}{l}\text { Lifestyle coaching aimed at weight reduction } \\
\text { and wellness improvement }(\mathrm{T})\end{array}$ & $\begin{array}{l}\text { Telecoach Team } \\
\text { (training by a } \\
\text { psychiatrist), patients }\end{array}$ & $\begin{array}{l}\text { Significant weight reductions and } \\
\text { improvements in general health }\end{array}$ & - & - \\
\hline $\begin{array}{l}\text { Balasinorwala } \\
\text { et al. (21) }\end{array}$ & India & Asynchronous & E-mail & $\begin{array}{l}\text { To assess the feasibility of telepychiatriy and } \\
\text { referral pattern (D) }\end{array}$ & $\begin{array}{l}\text { Primary care } \\
\text { physicians, } \\
\text { psychiatrist }\end{array}$ & $\begin{array}{l}\text { It is a reliable method and the most common } \\
\text { problems for referrals were schizophrenia }\end{array}$ & - & - \\
\hline $\begin{array}{l}\text { Hargreaves } \\
\text { et al. (22) }\end{array}$ & Ireland & Synchronous & $\begin{array}{l}\text { Online web } \\
\text { training } \\
\text { program } \\
\text { (auditory } \\
\text { and visual) } \\
\text { + call }\end{array}$ & $\begin{array}{l}\text { To examine the effects of cognitive } \\
\text { remediation (CR); training on } \\
\text { neuropsychological performance (E) }\end{array}$ & Patient, therapist & $\begin{array}{l}\text { Improved cognitive performance and } \\
\text { cognitive remediation therapy }\end{array}$ & - & - \\
\hline $\begin{array}{l}\text { Narasimhan } \\
\text { et al. (23) }\end{array}$ & Columbia & Synchronous & $\begin{array}{c}\text { Video } \\
\text { conference }\end{array}$ & $\begin{array}{l}\text { To examine rates of outpatient; follow-up and } \\
\text { inpatient service use and cost }(\mathrm{T})\end{array}$ & Psychiatrist, patient & $\begin{array}{l}\text { Better outpatient follow-up; lower } \\
\text { hospitalization rates; a shorter length of stay; } \\
\text { reduced inpatient service use }\end{array}$ & $\sqrt{ }$ & - \\
\hline $\begin{array}{l}\text { Seghers et } \\
\text { al. (24) }\end{array}$ & Singapore & Synchronous & $\begin{array}{l}\text { Video } \\
\text { conference }\end{array}$ & $\begin{array}{l}\text { Effectiveness of tele dermatology for } \\
\text { psychiatric patients (D) }\end{array}$ & Dermatologist, patient & $\begin{array}{l}\text { As effective as a F2F and high level of } \\
\text { agreement }\end{array}$ & $\sqrt{ }$ & $\sqrt{ }$ \\
\hline $\begin{array}{l}\text { Spaniel et } \\
\text { al. (25) }\end{array}$ & $\begin{array}{c}\text { Czech } \\
\text { Republic }\end{array}$ & Asynchronous & SMS, E-mail & To reduce the number of hospitalizations $(\mathrm{T})$ & $\begin{array}{l}\text { Patients, family } \\
\text { members, psychiatrist, } \\
\text { investigator }\end{array}$ & $\begin{array}{l}\text { No statistically significant differences were } \\
\text { found in patient survival; There were no } \\
\text { differences in the number of inpatient days }\end{array}$ & . & . \\
\hline $\begin{array}{l}\text { Kasckow } \\
\text { et al. (26) }\end{array}$ & USA & Hybrid & Text, call & $\begin{array}{l}\text { Feasibility of the monitoring for suicidal } \\
\text { behavior }(\mathrm{E} \& \mathrm{~T})\end{array}$ & Clinical Staff, Veterans & $\begin{array}{l}\text { Decreasing suicidal thoughts; Improving } \\
\text { medication adherence, and symptom } \\
\text { reduction for anxiety and depression }\end{array}$ & - & - \\
\hline $\begin{array}{l}\text { Flaherty } \\
\text { et al. (27) }\end{array}$ & USA & Hybrid & Call, text & $\begin{array}{l}\text { To examine rates of hospitalization and ER } \\
\text { visits (T) }\end{array}$ & Nurse, Veterans & $\begin{array}{l}\text { Decreased number and length of } \\
\text { hospitalization did not differ on ER visits }\end{array}$ & . & - \\
\hline $\begin{array}{l}\text { Krzystanek } \\
\text { et al. (28) }\end{array}$ & Poland & Synchronous & $\begin{array}{l}\text { Video con- } \\
\text { ferences }\end{array}$ & Improve compliance (T) & Psychiatrists, patients & $\begin{array}{l}\text { The treatment compliance was low and did } \\
\text { not improve }\end{array}$ & . & $\checkmark$ \\
\hline $\begin{array}{l}\text { Kim et al. } \\
(29)\end{array}$ & Korea & Synchronous & $\begin{array}{l}\text { Online } \\
\text { chat, call }\end{array}$ & cognitive-behavioral case management $(\mathrm{T})$ & Case manager, patients & $\begin{array}{l}\text { Useful for case management and promoting } \\
\text { communication between case managers and } \\
\text { clients }\end{array}$ & - & $\checkmark$ \\
\hline $\begin{array}{l}\text { Niendam } \\
\text { et al. }(30)\end{array}$ & USA & Asynchronous & Text & $\begin{array}{l}\text { feasibility of examining mood, symptoms, } \\
\text { medication adherence }(\mathrm{T})\end{array}$ & Patient, clinician & $\begin{array}{l}\text { Increased motivation for signs of } \\
\text { relapse/symptom management, treatment } \\
\text { engagement, and medication adherence. }\end{array}$ & - & $\checkmark$ \\
\hline $\begin{array}{l}\text { Schlosser } \\
(31)\end{array}$ & USA & Hybrid & $\begin{array}{c}\text { Call, } \\
\text { messages }\end{array}$ & Improving motivational impairment $(\mathrm{T})$ & $\begin{array}{l}\text { Patients together, } \\
\text { clinician }\end{array}$ & $\begin{array}{l}\text { was a feasible, acceptable, and efficacious } \\
\text { intervention }\end{array}$ & - & $\sqrt{ }$ \\
\hline $\begin{array}{l}\text { Spaniel et } \\
\text { al. (32) }\end{array}$ & $\begin{array}{c}\text { Czech } \\
\text { Republic }\end{array}$ & Asynchronous & E-mail, SMS & $\begin{array}{l}\text { To investigate the dynamics of prodromal } \\
\text { symptoms }(\mathrm{T})\end{array}$ & $\begin{array}{l}\text { Patient, member of } \\
\text { family, psychiatrist }\end{array}$ & $\begin{array}{l}\text { Was an effective early intervention for relapse } \\
\text { prevention }\end{array}$ & - & - \\
\hline $\begin{array}{l}\text { Krzystanek } \\
\text { et al. (33) }\end{array}$ & Poland & Synchronous & Video call & $\begin{array}{l}\text { To assess clinical condition, rates of } \\
\text { hospitalization, and visits to an outpatient } \\
\text { clinic }(E \& T)\end{array}$ & $\begin{array}{l}\text { Investigator, physician, } \\
\text { patient }\end{array}$ & $\begin{array}{l}\text { A significant reduction of symptoms did not } \\
\text { influence the rate of hospitalization and visits }\end{array}$ & - & . \\
\hline $\begin{array}{l}\text { Schulze et } \\
\text { al. (34) }\end{array}$ & Germany & Hybrid & $\begin{array}{l}\text { Call, } \\
\text { message }\end{array}$ & To improve adherence to medication $(\mathrm{T})$ & Patient, nurse & $\begin{array}{l}\text { Better medication adherence after hospital } \\
\text { discharge }\end{array}$ & - & - \\
\hline
\end{tabular}




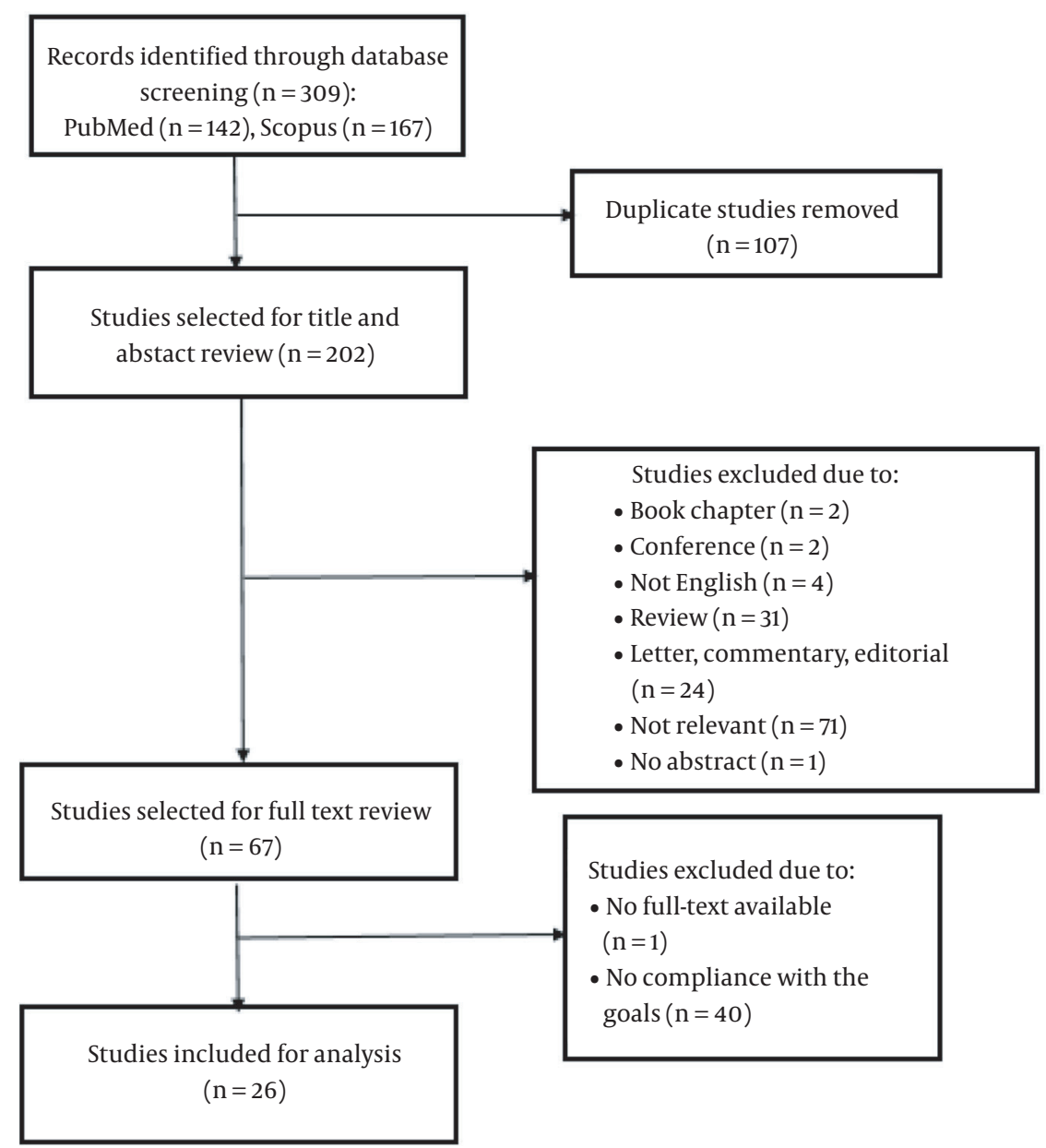

Figure 1. The flow diagram to select studies

\subsection{Country}

Seven studies were conducted in the United States (27\%), four studies in the Czech Republic (15.5\%). Each of Ireland, Korea, and Poland countries did two studies $(n=6$, $23 \%$ ). The rest of the studies were performed in other countries $(n=9,34.5 \%)$.

\subsection{Telemedicine Modality}

The synchronous modality was used in most studies (n $=15,58 \%$ ). The asynchronous method was used in six studies (23\%), and the hybrid was used in five studies (19\%).

\subsection{Telecommunication Method}

Videoconference communication is the most used approach in studies $(\mathrm{n}=10,38.5 \%)$. After it, telecommunication was performed mostly with text such as SMS, E-mail, and message ( $n=7,27 \%)$, call $(n=2,7.5 \%)$, and both call and text $(n=4,15.5 \%)$. The remaining studies used different telecommunication approaches $(n=3,11.5 \%)$.

\subsection{Objective}

Telemedicine services were used for three main purposes (diagnosis, treatment, and education) in the studies. In fifteen studies (58\%), telemedicine services were used for the objectives of the treatment of patients with schizophrenia. The objectives of the treatment could include medication adherence and preventive treatments such as prevent relapse of schizophrenia and reduce readmission, and hospitalization rates. In five studies (19\%), telemedicine was used to prove the reliability of these types of services for diagnosis. Three studies (11.5\%) used telemedicine to offer educational information for patients and their caregivers. In three remain studies (11.5\%), both treatment and educational objectives were addressed. Among the reviewed studies, two (7.5\%) studies 
provided non-psychiatric services such as lifestyle and dermatology services for patients with schizophrenia using telemedicine.

\subsection{Participants}

In more than half of the studies ( $n=16,62 \%$ ), the telemedicine services were provided between patients and healthcare providers. In five studies (19\%), these services were provided between patients and caregivers (families, support members) with healthcare providers. In the remaining studies, communications were done between caregivers or families and healthcare providers $(n=2,7.5 \%)$, between patients and raters or evaluators $(n=2,7.5 \%)$, and between healthcare providers $(n=1,4 \%)$.

\subsection{Outcomes}

There were clinical, cost-effectiveness, and satisfaction outcomes in the studies:

\subsubsection{Clinical}

Twenty-two studies (84.5\%) showed that telemedicine is a useful method to provide healthcare services for patients with schizophrenia. The result of one study (4\%) showed that although the symptoms of patients with schizophrenia were significantly reduced after using telemedicine services, these services could not reduce the number of hospitalization and visits (33). The other study (4\%) showed that telemedicine services could reduce hospitalization rate, but it could not decrease emergency room visits (27). Two studies (7.5\%) showed that telemedicine was not effective to increase patients' survival, reduce inpatient days, and improve treatment compliance $(25,28)$. Five studies $(19 \%)$ showed that telemedicine was a reliable method.

\subsubsection{Cost-effectiveness}

Only five studies (19\%) addressed the cost of telemedicine services used and one study (4\%) showed this service could not reduce the costs of the healthcare system (8).

\subsubsection{Satisfaction}

Nine studies (34.5\%) addressed the satisfaction of those who participated in telemedicine services and showed that all participants were satisfied. For satisfaction criteria, we considered all articles which had reported satisfaction, acceptance of patient and clinician, engagement of patients, ease of use, convenience of the participant, and like that as an effective factor in satisfaction.

\section{Discussion}

The aim of this study was to review the articles for investigating the applications and outcomes of telemedicine in providing healthcare services for patients with schizophrenia. The results showed that telemedicine could be an effective method for managing patients with schizophrenia. Two studies showed that telemedicine could be effective in some processes of schizophrenia management. For example, in Krzystanek's study, symptoms of patients with schizophrenia were significantly reduced (33). Moreover, in Flaherty's study, telemedicine could decrease hospitalization rates (27). The reason for these positive impacts of telemedicine could be due to proper use of telecommunication technology and comprehensive needs assessment before implementing telemedicine service. Readiness assessment, needs assessment, feasibility evaluation before implementing any telemedicine service could result in positive impact on the management of disease. However, two studies showed that telemedicine services were not efficient in increasing patients' survival, reducing inpatient days, and improving treatment adherence $(25,28)$. These studies mentioned some reasons for these negative results, such as the low level of patients and psychiatrists' cooperation in the intervention and the conditions of patients participating in the study. On the one hand, the number of these studies with a negative result is small, and on the other hand, this result is influenced by the study conditions. Therefore, we can conclude that telemedicine can be a beneficial method for providing remote healthcare services to manage schizophrenia.

Telemedicine was used mostly for the treatment purposes. These objectives were mainly included preventing relapse of schizophrenia symptoms and improving treatment adherence of patients with schizophrenia. Schizophrenia is a chronic and serious mental disorder. Accompanying schizophrenia with other diseases, stressful conditions, alcohol use, and irregular use of prescribed medications can increase these symptoms (35). Antipsychotic medications and psychosocial supports are used for the treatment of patients with schizophrenia (1). The patient's adherence to prescribed medications is the critical issue in the management process of schizophrenia to reduce the symptoms and avoid the relapse significantly (36). Relapse may increase the risk of readmission and hospitalization that imposes a cost to healthcare systems and patients' families. Therefore, relapse prevention is a primary aim for the successful treatment of schizophrenia. The importance of adherence to the treatment and prevention of relapse in schizophrenia caused telemedicine has been used more for these purposes. The results of our 
study showed that telemedicine could help effectively to reach these purposes. Despite the benefits of telemedicine to help patients with schizophrenia, there are challenges in using this technology effectively. These challenges included the existence of technological delusions or technophobia in patients, the absence of visual body language that may affect the proper diagnosis, and impossibility of monitoring the correct administration of psychotic drugs based on weight and body mass index (37).

Some patients with schizophrenia with mild symptoms can live without support; however, other patients with severe symptoms need assistance. A study showed that caregivers who have not received education about schizophrenia experience higher stigma (38). Therefore, education of patients and their caregivers is essential to increase their knowledge about this disease and proper encounter with it. Furthermore, adequate education may lead to increase patients' adherence to treatment, prevent schizophrenia symptoms relapse and then decrease hospitalization rate. Although studies showed telemedicine is a useful method for providing educational services in schizophrenia $(15,31)$, few studies used telemedicine for this purpose.

The synchronous telemedicine modality was used mostly to provide healthcare services for patients with schizophrenia. In more than one-third of the studies, telecommunication was established through videoconferencing. On the one hand, the issue of stigma and the unwillingness to be present in the community in mental illness causes many patients do not have access to the necessary health care services. On the other hand, in the management and treatment of mental illness, face-to-face communication is important between the physician and the patient. Therefore, telemedicine services can be beneficial in these types of diseases (39). As the results showed, synchronous methods, especially videoconferencing, due to their ability to communicate face to face, provide a sense of face-to-face visits for the patient and therapist and are mostly used in this field. A study that reviewed articles up to 2010 showed that telephone, internet, and videoconferencing methods were used almost equally in managing patients with schizophrenia (10). This difference between the results of two studies showed that in the last ten years, with progress in information and communication technologies, the traditional only audio-based methods have been replaced by audio-video-based methods to communicate between physicians and patients with schizophrenia. However, the other study showed that asynchronous telemedicine modality could have a positive impact on decreasing costs and increasing access to psychiatric services (40). Therefore, this modality in comparison with synchronous modality, can be used in regions that have not perfect information technology infrastructure in providing telepsychiatric services (41).

A study has shown that most patients with schizophrenia live in low- and middle-income countries. In these countries, the medical services provided to these patients are also minimal. The disease burden of schizophrenia in lower- and upper-middle-income countries is higher than in high-income countries (42). Telemedicine services may provide access to the necessary medical services for this group of patients and help them improve their life situations $(31,33)$. However, our study showed that most of the studies on telemedicine services were conducted in developed countries. One reason is that developed countries such as the United States are pioneers in the use of telemedicine services and have even enacted laws in this area (43). Considering the positive effects that telemedicine has shown in the management of schizophrenia, it is suggested that developing countries use this technology more to improve the condition of these patients.

Few studies have discussed the cost-effectiveness and user satisfaction of telemedicine services used. Except one study (8), others showed that telemedicine services used in schizophrenia were cost-effective. All nine studies that considered user satisfaction showed that all users were satisfied. However, only four of these nine studies used an appropriate tool, such as a questionnaire for evaluating satisfaction $(8,17,30,31)$. The rest of the studies only mentioned the effective factors in user satisfaction as acceptance, engagement, convenience, and ease of use. Since the number of studies that evaluated the cost and satisfaction outcomes is low, further researches are needed to reach more accurate and reliable results.

Although this is a comprehensive review study on telemedicine applications in schizophrenia, it also has few limitations. We used only two PubMed and Scopus databases to access relevant resources. Furthermore, we restricted our search to the "title and abstract" field in the Scopus database. Also, we used limited keywords and we included only original articles. Therefore, some articles may have been missed in our study. We did not use the PRISMA checklist for conducting this review. Moreover, we did not perform pooled-analysis to reach more accurate results.

In conclusion, considering an estimate of one percent prevalence of schizophrenia and normal population, it seems there is a high need psychiatrists and hospital beds for the management of patients with schizophrenia. Stigma is another issue that makes it difficult for family of patients with schizophrenia to take their patient to clinics and hospitals to be visited by psychiatrists. All of the abovementioned challenges emphasize that implementing and 
tele-consulting systems for visit of schizophrenia patients would reduce need to face-to-face visits and would reduce the need for hospitalization of patients. Telemedicine can be used as an effective method to replace face-to-face visits when patients with schizophrenia have stigma to appear in community, also have limited access to mental healthcare during COVID-19 pandemic. It is an efficient method for the management of patients with schizophrenia, especially to improve adherence to treatment and prevent relapse. It should be noted that the privacy and security of telemedicine systems are significant concerns that impact the effective use of telemedicine. Healthcare providers and policymakers should consider telemedicine to provide healthcare services and establish comprehensive regulations to ensure patients' privacy. However, it would be better to pay more attention to use telemedicine for the patients and their caregivers' education to increase their knowledge about schizophrenia in future studies.

\section{Acknowledgments}

We thank the Institute for Futures Studies in Health of Kerman University of Medical Sciences for providing research environment.

\section{Footnotes}

Authors' Contribution: S. Hajesmaeel Gohari, K. Bahaadinbeigy, and M. Hosseini Golkar contributed to the concept and design of the study. Selection and evaluation of the papers, and data extraction were performed by S. Keshvardoost and E. Shafiei. S. Keshvardoost, and S. Hajesmaeel Gohari participated in drafting the manuscript. All authors read and approved the final version of the manuscript.

Conflict of Interests: The authors declared that there is no conflict of interest.

Funding/Support: This research did not receive any specific grants from funding agencies in the public, commercial, or not-for-profit sectors.

\section{References}

1. World Health Organization. Schizophrenia 2019. World Health Organization; 2019, [cited 4/10/2019]. Available from: https://www.who.int/ news-room/fact-sheets/detail/schizophrenia.

2. National Institute of Mental Health. Schizophrenia. National Institute of Mental Health; 2018. Available from: https://www.nimh.nih.gov/ health/statistics/schizophrenia.shtml.

3. Tajima-Pozo K, de Castro Oller MJ, LewczukA, Montanes-Rada F. Understanding the direct and indirect costs of patients with schizophrenia. F1000Res. 2015;4:182. doi: 10.12688/f1000research.6699.2. [PubMed: 26339474]. [PubMed Central: PMC4544407].

4. Pokos V, Castle D. Prevalence of Comorbid Anxiety Disorders in Schizophrenia Spectrum Disorders: A Literature Review. Curr Psychiatry Rev. 2006;2(3):285-307. doi: 10.2174/157340006778018193.
5. Muhorakeye O, Biracyaza E. Exploring Barriers to Mental Health Services Utilization at Kabutare District Hospital of Rwanda: Perspectives From Patients. Front Psychol. 2021;12:638377. doi: 10.3389/fpsyg.2021.638377. [PubMed: 33828506]. [PubMed Central: PMC8019821].

6. Saeed SA, Diamond J, Bloch RM. Use of telepsychiatry to improve care for people with mental illness in rural North Carolina. N C Med J. 2011;72(3):219-22. [PubMed: 21901921].

7. Spaniel F, Vohlidka P, Hrdlicka J, Kozeny J, Novak T, Motlova L, et al. ITAREPS: information technology aided relapse prevention programme in schizophrenia. Schizophr Res. 2008;98(1-3):312-7. doi: 10.1016/j.schres.2007.09.005. [PubMed: 17920245].

8. Modai I, Jabarin M, Kurs R, Barak P, Hanan I, Kitain L. Cost effectiveness, safety, and satisfaction with video telepsychiatry versus face-toface care in ambulatory settings. Telemed JE Health. 2006;12(5):515-20. doi: 10.1089/tmj.2006.12.515. [PubMed:17042703].

9. Zhou X, Snoswell CL, Harding LE, Bambling M, Edirippulige S, Bai $\mathrm{X}$, et al. The Role of Telehealth in Reducing the Mental Health Burden from COVID-19. Telemed J E Health. 2020;26(4):377-9. doi: 10.1089/tmj.2020.0068. [PubMed: 32202977].

10. Kasckow J, Felmet K, Appelt C, Thompson R, Rotondi A, Haas G. Telepsychiatry in the assessment and treatment of schizophrenia. Clin Schizophr Relat Psychoses. 2014;8(1):21-27A. doi: 10.3371/CSRP.KAFE.021513. [PubMed: 23428781]. [PubMed Central: PMC4132656].

11. Chae YM, Park HJ, Cho JG, Hong GD, Cheon K. The reliability and acceptability of telemedicine for patients with schizophrenia in Korea. J Telemed Telecare. 2016;6(2):83-90. doi:10.1258/1357633001935095.

12. Yoshino A, Shigemura J, Kobayashi Y, Nomura S, Shishikura K, Den $\mathrm{R}$, et al. Telepsychiatry: assessment of televideo psychiatric interview reliability with present- and next-generation internet infrastructures. Acta Psychiatr Scand. 2001;104(3):223-6. doi: 10.1034/j.16000447.2001.00236.x.

13. Shen J, Kobak KA, Zhao Y, Alexander MM, Kane JM. Use of Remote Centralized Raters Via Live 2-Way Video in a Multicenter Clinical Trial for Schizophrenia. J Clin Psychopharmacol. 2008;28(6):691-3. doi: 10.1097/JCP.ob013e31818c9ba3.

14. Rotondi AJ, Anderson CM, Haas GL, Eack SM, Spring MB, Ganguli R, et al. Web-Based Psychoeducational Intervention for Persons With Schizophrenia and Their Supporters: One-Year Outcomes. Psychiatr Serv. 2010;61(11):1099-105. doi: 10.1176/ps.2010.61.11.1099.

15. Haley C, O'Callaghan E, Hill S, Mannion N, Donnelly B, Kinsella A, et al. Telepsychiatry and carer education for schizophrenia. Eur Psychiatry. 2020;26(5):302-4. doi: 10.1016/j.eurpsy.2009.12.021.

16. Franco-Martin MA, Bernardo-Ramos M, Soto-Perez F. CyberNeuropsychology: application of new technologies in neuropsychological evaluation. Actas Esp Psiquiatr. 2012;40(6). [PubMed: 23165413].

17. Godleski L, Cervone D, Vogel D, Rooney M. Home telemental health implementation and outcomes using electronic messaging.JTelemed Telecare. 2011;18(1):17-9. doi:10.1258/jtt.2011.100919.

18. ŠPaniel F, HrdliČKa JAN, NovÁK T, KoŽEnÝ J, HÖSchl C, Mohr P, et al. Effectiveness of the Information Technology-Aided Program of Relapse Prevention in Schizophrenia (ITAREPS). J Psychiatr Pract. 2012;18(4):269-80. doi: 10.1097/01.pra.0000416017.45591.c1.

19. Ozkan B, Erdem E, Demirel Ozsoy S, Zararsiz G. Effect of psychoeducation and telepsychiatric follow up given to the caregiver of the schizophrenic patient on family burden, depression and expression of emotion. PakJ Med Sci. 2013;29(5). doi: 10.12669/pjms.295.2613.

20. Temmingh $\mathrm{H}$, Claassen A, van Zyl S, Carrara $H$, Dayakalashe NM, Myer L, et al. The Evaluation of a Telephonic Wellness Coaching Intervention for Weight Reduction and Wellness Improvement in a Community-Based Cohort of Persons With Serious Mental Illness. J Nerv Ment Dis. 2013;201(11):977-86. doi: 10.1097/nmd.0000000000000036. 
21. Balasinorwala VP, Shah NB, Chatterjee SD, Kale VP, Matcheswalla YA. Asynchronous Telepsychiatry in Maharashtra, India: Study of Feasibility and Referral Pattern. Indian J Psychol Med. 2014;36(3):299-301. doi: 10.4103/0253-7176.135384.

22. Hargreaves A, Dillon R, Anderson-Schmidt H, Corvin A, Fitzmaurice B, Castorina $\mathrm{M}$, et al. Computerised working-memory focused cognitive remediation therapy for psychosis - A preliminary study. Schizophr Res. 2015;169(1-3):135-40. doi: 10.1016/j.schres.2015.09.004.

23. Narasimhan M, Druss BG, Hockenberry JM, Royer J, Weiss P, Glick G, et al. Impact of a Telepsychiatry Program at Emergency Departments Statewide on the Quality, Utilization, and Costs of Mental Health Services. Psychiatr Serv. 2015;66(11):1167-72. doi: 10.1176/appi.ps.201400122.

24. Seghers AC, Seng KH, Chio MT, Chia E, Ng SK, Tang MB. A prospective study on the use of teledermatology in psychiatric patients with chronic skin diseases. Aust J Dermatol. 2015;56(3):170-4. doi: 10.1111/ajd.12297.

25. Spaniel F, Novak T, Bankovska Motlova L, Capkova J, Slovakova A, Trancik P, et al. Psychiatrist's adherence: a new factor in relapse prevention of schizophrenia. A randomized controlled study on relapse control through telemedicine system. J Psychiatr Ment Health Nurs. 2015;22(10):811-20. doi: 10.1111/jpm.12251.

26. Kasckow J, Zickmund S, Gurklis J, Luther J, Fox L, Taylor M, et al. Using telehealth to augment an intensive case monitoring program in veterans with schizophrenia and suicidal ideation: A pilot trial. Psychiatry Res. 2016;239:111-6. doi:10.1016/j.psychres.2016.02.049.

27. Flaherty LR, Daniels K, Luther J, Haas GL, Kasckow J. Reduction of medical hospitalizations in veterans with schizophrenia using home telehealth. Psychiatry Res. 2017;255:153-5. doi: 10.1016/j.psychres.2017.05.024.

28. Krzystanek M, Krysta K, Skałacka K. Treatment Compliance in the Long-Term Paranoid Schizophrenia Telemedicine Study. J Technol Behav Sci. 2017;2(2):84-7. doi: 10.1007/s41347-017-0016-4.

29. Kim S, Lee G, Yu H, Jung EI, Lee J, Kim S, et al. Development and feasibility of smartphone application for cognitive-behavioural case management of individuals with early psychosis. Early Interv Psychiatry. 2018;12(6):1087-93. doi: 10.1111/eip.12418.

30. Niendam TA, Tully LM, Iosif A, Kumar D, Nye KE, Denton JC, et al. Enhancing early psychosis treatment using smartphone technology: a longitudinal feasibility and validity study.JPsychiatr Res. 2018;96:23946. doi:10.1016/j.jpsychires.2017.10.017. [PubMed: 29126059].

31. Schlosser DA, Campellone TR, Truong B, Etter K, Vergani S, Komaiko $\mathrm{K}$, et al. Efficacy of PRIME, a mobile app intervention designed to improve motivation in young people with schizophrenia. Schizophr Bull. 2018;44(5):1010-20. doi: 10.1093/schbul/sby078. [PubMed: 29939367]. [PubMed Central: PMC6101497].

32. Spaniel F, Bakstein E, Anyz J, Hlinka J, Sieger T, Hrdlicka J, et al. Relapse in schizophrenia: definitively not a bolt from the blue. Neu- rosci Lett. 2018;669:68-74. doi: 10.1016/j.neulet.2016.04.044. [PubMed: 27109788].

33. Krzystanek M, Borkowski M, Skałacka K, Krysta K. A telemedicine platform to improve clinical parameters in paranoid schizophrenia patients: Results of a one-year randomized study. Schizophr Res 2019;204:389-96. doi: 10.1016/j.schres.2018.08.016.

34. Schulze LN, Stentzel U, Leipert J, Schulte J, Langosch J, Freyberger $\mathrm{HJ}$, et al. Improving medication adherence with telemedicine for adults with severe mental illness. Psychiatr Serv. 2019;70(3):225-8. doi: 10.1176/appi.ps.201800286. [PubMed: 30651059].

35. American Psychiatric Association. Schizophrenia. American Psychiatric Association; 2020. Available from: https://www.psychiatry.org/ patients-families/schizophrenia/what-is-schizophrenia..

36. García S, Martinez-Cengotitabengoa M, Lopez-Zurbano S, Zorrilla I, Lopez P, Vieta E, et al. Adherence to antipsychotic medication in bipolar disorder and schizophrenic patients: a systematic review.J Clin Psychopharmacol. 2016;36(4):355. doi: 10.1097/JCP.0000000000000523. [PubMed: 27307187].

37. Maguire PA, Looi JC. COVID-19 telehealth challenges for patients with schizophrenia and other psychoses. Aust $N$ Z J Psychiatry. 2020:4867420968887. doi: 10.1177/0004867420968887. [PubMed: 33092391].

38. Karaçar Y, Bademli K. Relationship between perceived social support and self stigma in caregivers of patients with schizophrenia. Int J Soc Psychiatry. 2021:207640211001886. doi: 10.1177/00207640211001886. [PubMed: 33730905].

39. Lal S, Abdel-Baki A, Sujanani S, Bourbeau F, Sahed I, Whitehead J. Perspectives of young adults on receiving telepsychiatry services in an urban early intervention program for first-episode psychosis: a cross-sectional, descriptive survey study. Front Psychiatry. 2020;11:117. doi: 10.3389/fpsyt.2020.00117. [PubMed: 32194457]. [PubMed Central: PMC7065530].

40. O'Keefe M, White K, Jennings JC. Asynchronous telepsychiatry: A systematic review. J Telemed Telecare. 2021;27(3):137-45. doi: 10.1177/1357633X19867189. [PubMed: 31357908].

41. Hilty DM, Parish MB, Chan S, Torous J, Xiong G, Yellowlees PM. A comparison of in-person, synchronous and asynchronous telepsychiatry: skills/competencies, teamwork, and administrative workflow. J Technol Behav Sci. 2020;5(3):273-88. doi: 10.1007/s41347-020-00137-8.

42. Charlson FJ, Ferrari AJ, Santomauro DF, Diminic S, Stockings E, Scott JG, et al. Global epidemiology and burden of schizophrenia: findings from the global burden of disease study 2016. Schizophr Bull. 2018;44(6):1195-203. doi: 10.1093/schbul/sby058. [PubMed: 29762765]. [PubMed Central: PMC6192504].

43. Board on Health Care Services Institute of Medicine. The Role of Telehealth in an Evolving Health Care Environment. Washington DC, USA: National Academies Press; 2012. 